\title{
Sociedade Brasileira de Ornitologia: a history
}

\author{
Elizabeth Höfling ${ }^{1,2}$, Luiz dos Anjos ${ }^{3}$, Pedro Scherer-Neto ${ }^{4}$, Paulo de Tarso Zuquim Antas ${ }^{5}$ \\ \& Carla Suertegaray Fontana ${ }^{6,7}$
}

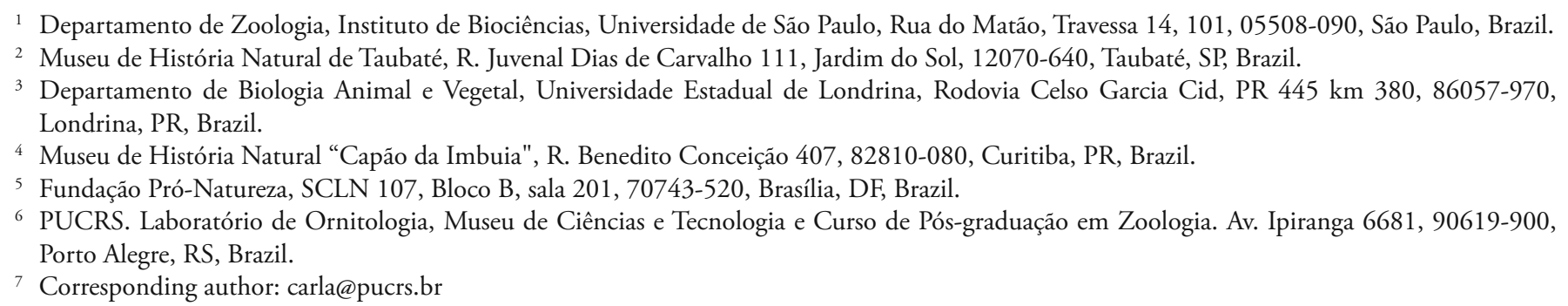

Received on 11 December 2017. Accepted on 03 March 2018.

Our Brazilian Ornithological Society (Sociedade Brasileira de Ornitologia - SBO) was born 30 years ago. The aim of this Editorial is provide a point-of-view of relevant facts that lead the establishment of the SBO, and some key (despite not exhaustive) facts along these three decades.

The $20^{\text {th }}$ Century was an important period for the development of ornithology as a science in Brazil (see Pinto 1979, Paynter-Jr. 1991, Belton 1994, Sick 1997, Alves \& Silva 2000, Aleixo \& Straube 2007, Fontana et al. 2017). The German ornithologist and naturalist Emilie Snethlage (who worked at the Museu Paraense Emílio Goeldi and Museu Nacional), Olivério Pinto (ornithologist from the Museu Paulista, today Museu de Zoologia da Universidade de São Paulo) and another German ornithologist, Helmut Sick (from the Museu Nacional, Rio de Janeiro), were amongst those who made substantial contributions to build the knowledge of our birds. In addition to undertaking extensive expeditions to different Brazilian biomes, they were responsible for innumerable publications and also scientific collections that were fundamental for the development of ornithology until now.

However, prior to the creation of the SBO, some Brazilian institutions and universities already had researchers dedicated to the study of birds, although they still had only limited integration, largely due to the physical distances separating them in a country of continental size, besides other logistic difficulties. The first entity - the Clube de Observadores de Aves (COA) of Rio Grande do Sul - aimed to bring together those interested in ornithology and bird watching arose in the 1970 's. William "Bill" Belton, a retired but influential north-American diplomat and passionate birdwatcher in Rio Grande do Sul, was the mentor in 1974 of this first birdwatcher club.

This initiative was followed by other clubs of birdwatching in various states of Brazil, such as the Centro de Estudos Ornitológicos (CEO) founded in 1984, in the Departamento de Zoologia of the Instituto de Biociências of the Universidade de São Paulo. A decade before the founding of the SBO, in 1977, the CEMAVE (formerly named Centro de Estudos de Migraçōes de Aves) was founded at a national level by the Instituto Brasileiro de Desenvolvimento Florestal [Brazilian Institute for Forestry Development], whose first course in bird watching was ministered by Bill Belton, with the participation of Helmut Sick. Today the CEMAVE is one of the 13 National Centers for Research and Conservation under the auspices of the Instituto Chico Mendes de Conservação da Biodiversidade (ICMBio). These entities, the CEMAVE, COAs and CEO, were seeds for the future development of the SBO.

At the onset of the 1980's amateur and professional ornithologists organized a series of meetings that brought together ornithologists at local and national levels, especially the Encontros de Anilhadores de Aves [birdbanders meetings] promoted by CEMAVE, the first of which was held at Universidade Federal de Viçosa (Minas Gerais) from 02 to 24 January of 1985. At these events, contacts between ornithologists were gradually increased and gave rise to the idea of the creation of a national entity in the form of a society that would bring together people interested in ornithology and also a regular meeting of this society.

Subsequently, the first attempts to organize a society dedicated to the study of birds occurred within the scope of the congresses of the Sociedade Brasileira de Zoologia (SBZ) by way of the Brazilian Ornithological Meetings. Thus, in 1984, on the occasion of the XI Congress of the SBZ in Belém (Pará), during the II Encontro Brasileiro de Ornitologia, on 16 February, the creation of the SBO was proposed. At that time there were in Brazil only a few 
professional ornithologists working in different national institutions, but many students were interested in the study of birds.

In the following year, 1985, during the XII Congresso Brasileiro de Zoologia held in Campinas (São Paulo), a new meeting affirmed the foundation of the SBO, and ruled that participants who signed up, in addition to those who signed prior to the official founding date, would be considered as founding members of the society.

In February 1987, during the XIV Congresso Brasileiro de Zoologia in Juiz de Fora (Minas Gerais) the first Board of Directors (1987-1989) of the SBO was elected, with Roberto Brandão Cavalcanti as president, Maria Alice dos Santos Alves as secretary, and Paulo de Tarso Zuquim Antas as treasurer. The first Deliberative Council (1985-1989) was composed by Jacques M.E. Vielliard, Pedro Scherer Neto and David Oren. They were responsible for all of the initial organizational work for the new society, and they had to overcome many obstacles to get it established.

Subsequently, on 16 July 1987, at the III Encontro Nacional de Anilhadores de Aves, held at the Universidade do Rio dos Sinos (UNISINOS), in São Leopoldo (Rio Grande do Sul), the creation of the SBO was formally established during an extraordinary meeting of the General Assembly.

SBO was officially founded on the 13 November (supplement of the Diário Oficial do Distrito Federal, 1987, number 214, page 36) with a summary of the objectives of the society: to bring together people interested in ornithology, represent the community of Brazilian ornithologists national and internationally, promote and provide courses, lectures, meetings and regional, national and/or international congresses, stimulate the conservation of the avifauna, spread knowledge about ornithology, and bring together within the scope of the SBO organized groups dedicated to diverse aspects of ornithology. The board of directors of the SBO is elected each two years, and comprises a chair, two secretaries and two treasures members, beside a deliberative supervisory board (see statute at www.ararajuba.org.br).

The founding document for the society reported 72 founding members, most of whom were biologists, of which 16 were undergraduate students, and of the remaining 56 , many were undertaking graduate studies. This founding minute was registered at the notary's office in Brasília, DF, on 25 November 1987.

In February 1988, during the General Assembly meeting of the SBO, at the XV Congresso Brasileiro de Zoologia in Curitiba (Paraná), it was decided that the date for future ornithological meetings should still coincide with those of the Congresso Brasileiro de Zoologia; it was also decided that the value of the annual subscription for the SBO would be fixed at 1 OTN (a Brazilian monetary index in use until 1989) for regular members, and half this for student members. The national currency was the cruzado, and 1 OTN corresponded to Cz\$ 695.50, but its value was in constant flux (dollar variation was from $\mathrm{Cz} \$$ 71.89 to $\mathrm{Cz} \$ 761.49$ along the year of 1988).

At the beginning, to communicate with their members, SBO used a printed informative bulletin (Boletim da SBO) of which the first issue was published in January/February 1988 with José Maria Cardoso da Silva as editor. The bulletins, which were bimonthly until 1990 were interrupted in 1991, and resumed with the editor Walter Voss in 1992 in a biannual format until 1999. These bulletins featured, in addition to general notices, topics related to different species of birds, study groups, new discoveries, announcements of national and international meetings, the launch of journals in the area, articles published by members, news on banding of birds in Brazil, academic theses and dissertations that had been defended, and obituaries. The bulletins were distributed by surface mail and eagerly awaited by members who were keen to receive the ornithological news. It is important to recall that at this time this sort of communication was essential, as there was no other way to spread news in a large scale. The first virtual message was sent in Brazil in 1988, via Bitnet, a network that was only available in some universities. The internet as a tool for general communication only became available to the population at large in 1995.

Amongst other new items, in the first bulletin of 1988 it was announced that the first edition of the SBO scientific journal would be launched in 1989, with Luiz Antonio Pedreira Gonzaga as the editor-in-chief. The creation of the journal Ararajuba, Revista Brasileira de Ornitologia already featured in the statutes of the SBO in accordance with article 20. The first edition was published in August 1990, with 11 main papers, 8 short communications and 1 In Memoriam (Necrology). The cover of Ararajuba showed a hand-drawing of an Ararajuba (Guaruba guarouba) made by Carlos Yamashita until 2004 (volume 12, issue 21), when it started to show color photographs of birds. Ararajuba published two issues per year between 1996 and 2005. In 2005 (volume 13, issue 23) the journal's name was changed to Revista Brasileira de Ornitologia/Brazilian Journal of Ornithology, publishing four issues per year since 2006, and changing from printed to digital format since 2007. The Revista Brasileira de Ornitologia had published 69 issues in these 27 years. Today, the digital Revista Brasileira de Ornitologia, published in English and with four fascicles each year, is the main reference source for Brazilian ornithology, and has an emphasis on diverse studies of Neotropical birds. The impact factor of the Revista Brasileira de Ornitologia, measured by Journal Citation Reports was 0.414 in 2016.

Only in 1991, during the term of the second board chaired by Pedro Scherer Neto (1989-1991), the Meetings of SBO became independent from those 
organized by the Sociedade Brasileira de Zoologia; this was a signal of the scientific atmosphere and maturity of SBO in that period, which allowed the consolidation of the new society. It was also decided that the meetings of the SBO and those of the bird banders would be combined, given the great overlap of participants and the difficulties of attending two separate annual meetings in a country of continental size. The bird banding meetings occurred annually from 1985 until 1990. The last one was held in Pelotas and the book of abstracts comprised 37 contributions. In 1991, the first Congresso Brasileiro de Ornitologia (I CBO), held in Belém (Pará) already had 71 contributions from 78 authors. A significant feature was the participation by young students, and this has persisted for all of the congresses sponsored by SBO. The congresses have grown since then, with 106 abstracts from 124 authors at the II CBO held in 1992 in Cuiabá (Mato Grosso), to 350 abstracts and 500 registered participants at the last congress in Brazil (XXIII CBO), held in 2016 in Pirenópolis (Goiás).

Since the first Congresso Brasileiro de Ornitologia (I CBO) occurred in Belém in 1991, there have been 23 editions of the CBOs in different states of Brazil (eight in the north and northeast regions, three in the middlewest and 12 in southeast and south regions of Brazil). One exception occurred in 2010, when the $25^{\text {th }}$ International Ornithological Congress (IOC) was held in Campos de Jordão (São Paulo). This honorable exception occurred because it was the first time that this very traditional world event was held in South America, recognition of the level of development of ornithology in our country. In 2015, the Congresso Brasileiro de Ornitologia was held in Manaus (Amazonas), in conjunction with the Congreso de Ornitología Neotropical of the Neotropical Ornithological Society (NOS), again re-affirming the importance of the SBO in the Neotropics. In 2017, there was another international initiative by the SBO with the sponsoring of the Ornithological Congress of the Americas, held in Puerto Iguazú, Argentina, in conjunction with two societies: the Aves Argentinas (AA) and the Association of Field Ornithologists (AFO). Again, this international collaboration demonstrates the growing maturity of a young SBO that can promote international meetings with traditional societies of the world, such as the AA and AFO that are 100 and 95 years old, respectively.

We can bear witness to the fact that the SBO has already been through different phases, including some that were difficult to overcome. The number of regular paid-up members has fluctuated over the years (averaged 140 from 2012 to 2014), but there are usually around 100 members/year, some of them researchers who have accompanied the society since its foundation or for much of this time.

Meanwhile, although the number of members has not increased in proportion to the growth of knowledge in ornithology, currently celebrating its 30 years, we can affirm that the SBO is on firm foundations and is sustainable, especially since the Revista Brasileira de Ornitologia passed to a digital version published only in English. Its papers are widely cited, which guarantees regular publication of the journal and qualifies it for funding from the Brazilian scientific funders. As always, it depends on the great endeavors of its directors, advisers and editors, who are increasingly more experienced and have been greatly helped by new technologies, and associations with national institutions such as the Sociedade Brasileira do Zoologia (SBZ) and the Sociedade Brasileira para o Progresso da Ciência (SBPC).

The SBO, like other scientific societies in Brazil, depends on the interest and also the annual subscriptions of its members, since this is the only source of assured funds. It is always hoped that the Brazilian congresses have a positive balance that can be credited to the SBO, which has not been always achieved. However, welcome contributions from different institutions, like most of the SBO chair institutions or RBO Editors institutions helped the SBO. For example, the Museu Goeldi has provided facilities to manage and publish electronically manuscripts submitted to the Revista Brasileira de Ornitologia. CNPq, the Brazillian Council for Development of Science and Tecnology, supported the printed version of the Revista Brasileira de Ornitologia for several years and the online version along recent years.

During these 30 years Brazilian ornithology has significantly advanced in aspects such as the quality of the research done and the presence of members from most public and private universities, museums, and wildlife conservation institutions. Additionally, it broadly reaches out to the community via its website, participation by members in international and national committees (such as the Comitê Brasileiro de Registros Ornitológicos CBRO, the Official Brazilian Bird List), and in platforms such as Wikiaves and e-bird. Currently, there are several Masters and Doctoral graduate research programs that are forming students in areas related to ornithology, thus showing its importance.

New facilities for communication allow a constant increase in the contact between associates of the SBO, and doubtless research studies in progress will be improved by this enhanced integration. This new scenario is very different from that prevailing at the outset of Brazilian ornithology and it will open doors to a new era for research on Brazilian birds.

Of the 72 founding members of the SBO, some have retired, others have passed away, others continue to accompany us from a distance, and some continue to be active in the SBO. Currently, among the 90 members, about half (47) are undergraduate (19) or graduate (28) student members. It is worth recalling that of the young 
students who in 1987 contributed to the founding of the $\mathrm{SBO}$, some now have important roles in the academic formation of masters and doctoral students in the area of ornithology, and have become recognized international scientists. We hope that today's student members will follow the same path, with the same ideals as those who founded the SBO, and that with the vigor of these modern times they will be able to celebrate many more decades dedicated to the study of birds in Brazil.

\section{ACKNOWLEDGEMENTS}

Our thanks to all those who collaborated to create the $\mathrm{SBO}$, to all of the past and current members of the Board of Directors, all the Presidents of the Brazilian Ornithological Meetings (CBO's) and all Editors-inchief of the Boletim and the Ararajuba, Revista Brasileira de Ornitologia/Brazilian Journal of Ornithology. It is also important to mention the researchers and teachers from museums, universities, or other research institutions who produced and multiplied knowledge, particularly forming human resources. Those members have worked, and continue working, in the construction and maintenance of this 30 years of history. Leandro Bugoni, Miguel Marini and an anonymous reviewer made valuable suggestions to the manuscript.

\section{REFERENCES}

Aleixo A. \& Straube F.C. 2007. Coleçóes de aves brasileiras: breve histórico, diagnóstico atual e perspectivas para o futuro. Revista Brasileira de Ornitologia 15: 315-324.

Alves M.A.S. \& Silva J.M.C. 2000. A ornitologia no Brasil: desenvolvimento, tendências atuais e perspectivas, p. 327-344. In: Alves M.A.S., Silva J.M.C., van Sluys M., Bergallo H.G. \& Rocha C.F.D. A ornitologia no Brasil: pesquisa atual e perspectivas. Rio de Janeiro: Ed. UERJ.

Belton W. 1994. Aves do Rio Grande do Sul: distribuição e biologia. São Leopoldo: Editora Unisinos.

Fontana C.S., Silva T.W. da \& Souza J.P. 2017. Brazilian bird collections: a decade after Aleixo \& Straube (2007). Revista Brasileira de Ornitologia 25: 277-296.

Paynter-Jr. R.A. 1991. The maturation of Brazilian ornithology. Ararajuba 2: 105-106.

Pinto O.M.O. 1979. A ornitologia brasileira através das idades (Século XVI a século XIX). São Paulo: Editora Gráfica da Revista dos Tribunais.

Sick H. 1997. Ornitologia brasileira. Rio de Janeiro: Ed. Nova Fronteira.

Associate Editor: Leandro Bugoni. 